\title{
TINGKAT KELUHAN BERDASARKAN MENOPAUSE RATING SCALE PADA IBU MENOPAUSE
}

\section{THE LEVEL OF COMPLAINTS BASED ON MENOPAUSE RATING SCALE IN MENOPAUSE WOMEN}

\author{
Dewi Zolekhah ${ }^{1}$, Nur Rahmawati Sholihah \\ STIKES Jenderal Achmad Yani Yogyakarta \\ 1Email : dewizolekhah87@gmail.com
}

\begin{abstract}
ABSTRAK
Pada saat lahir, seorang wanita memiliki lebih kurang 1.500 .000 folikel di dalam rahim.. Seiring dengan bertambahnya usia atau karena suatu kondisi tertentu akan menyebabkan terjadinya penurunan kualitas dan kuantitas folikel sehingga ovulasi terhenti dan tidak terjadi ovulasi serta tidak terjadi lagi menstruasi. Apabila hal ini terus berlangsung selama 12 bulan maka terjadilah menopause. Tujuan penelitian ini adalah untuk mengetahui tingkat keluhan berdasarkan Menopause Rating Scale (MRS) pada ibu menopause di Desa Sanggrahan RW.09, Banyuraden, Sleman, Yogyakarta. Desain penelitian menggunakan survey deskriptif. Teknik pengambilan sampel menggunakan total sampling sebanyak 30 responden. Hasil penelitian menunjukkan sebagian besar wanita menopause mengalami gejala ringan pada keluhan psikologis berupa kering pada vagina (rasa kering atau terbakar pada vagina, sulit dalam berhubungan intim) sebanyak 24 responden $(80 \%)$.
\end{abstract}

Kata Kunci : Keluhan, Menopause Rating Scale, Menopause

\section{ABSTRACT}

At the birth, a woman has around 1,500,000 follicles in the ovarium. Due to the age factor or certain condition, quality and quantity of follicles decrease, so the ovulation is stopped and there is no ovulation and menstruation anymore. If this keeps happening for 12 months, the menopause will happen. In this case, there will be a worry about the change in the body function, so there were many complaints and women feel that they are not beautiful anymore. Purpose of Research: This research aims to see level of complaints based on Menopause Rating Scale (MRS) in menopause women in Sanggrahan Village, Local Citizen Council 09, Banyuraden, Sleman, Yogyakarta. The research design used descriptive survey. The sample technique used total sampling, with 30 respondents. The research showed that most of the menopause women had experience mild symptoms, such as psychological complaints in form of vaginal dryness (dry or burning sensation on the vagina, difficulty in sexual intercourse) amount 24 respondents $(80 \%)$.

Keywords: Complaint, Menopause Rating Scale, Menopause

\section{PENDAHULUAN}

Pada saat lahir, seorang wanita mempunyai 1.500 .000 kantong kelenjar yang sempit di dalam rahim (Folikel). Rata-rata setiap perempuan mengalami 400 kali ovulasi. Jika ovum yang dikeluarkan folikel tidak dibuahi maka ia akan keluar bersama dengan meluruhnya pembuluh darah di endometrium, peristiwa ini disebut dengan menstruasi (Sinclair, 2009). Bersamaan dengan semakin 
meningkatnya usia atau karena suatu kondisi tertentu akan menyebabkan terjadinya pengurangan volume folikel didalam rahim sehingga ovulasi terhenti serta tidak terjadi lagi menstruasi. Apabila hal ini terus berlangsung selama 12 bulan maka terjadilah menopause (Ferrari, 2009).

\section{World Helath Organization} (WHO) memperkirakan di tahun 2025 terdapat 1,2 milyar atau terjadinya peningkatan tiga kali lipat jumlah wanita berusia $>50$ tahun yang akan mengalami menopause. Sampai saat ini belum diketahui waktu yang pasti kapan terjadinya menopause. Sebagian besar perempuan akan menopause di usia 50 tahun akan tetapi bisa terjadi lebih awal atau lebih lambat (Mulyani, 2013).

Berdasarkan data Profil DIY (2013) perempuan menopause di Provinsi DIY tahun 2012 mencapai 3.9 ribu jiwa (10.73\%) dari total penduduk. wanita dengan usia 45-64 tahun terbanyak berada di Kabupaten Sleman yaitu sebanyak 128.755 jiwa (Dinkes DIY, 2013). Wanita dapat mengalami menopause pada usia yang berbedabeda, dapat terjadi pada usia 40 tahun, tetapi dapat terjadi juga pada usia 56 tahun. Sebuah penelitian dibeberapa kota di Indonesia menunjukkan bahwa rata-rata wanita di Indonesia mengalami menopause pada usia 48-49 tahun (Sinclair, 2009). Gejala fisik yang dialami oleh seorang perempuan yang memasuki fase menopause yaitu rasa panas yang merupakan sensasi tiba-tiba panas dan tubuh bagian atas berkeringat, berkeringat saat malam hari, sulit tidur, pusing, kesusahan menahan buang air kecil, detak jantung meningkat, dan berat badan semakin bertambah (Klein, 2004). Selain itu disertai dengan beberapa gejala psikis yang menonjol berupa suasana hati yang berubah ubah, sensitif, emosi labil, merasa tidak berharga, dan munculnya kecemasan yang menghambat aktifitas sehari-hari (Schorage, 2008). Kurang lebih $75 \%$ dari keluhan tersebut menimbulkan masalah bagi wanita menopause dan berdampak buruk kehidupannya sehingga dibutuhkan penanganan efektif dan efisien agar kualitas hidup wanita dimasa menopause tertap terjaga dengan baik (Ferrari, 2009). Dari hasil studi pendahuluan yang dilakukan di RW 08 Sanggrahan Banyuraden Sleman, didapatkan bahwa satu RW terdiri dari 5 RT dan jumlah wanita yang berusia 4050 tahun sebanyak 30 orang. 
Dari hasil wawancara kepada 8 wanita di RW 06 Sanggrahan terdapat 4 ibu yang mengatakan mengalami keluhan susah tidur di malam hari karena berkeringat berlebihan, 3 ibu mengatakan suasana hati berubah ubah, mudah tersinggung, dan $3 \mathrm{ibu}$ mengatakan vagina menjadi lebih kering dan menyebabkan sakit saat berhubungan seksual.

Dari hasil studi pendahuluan tersebut maka dilakukan penelitian tingkat keluhan berdasarkan Menopause Rating Scale (MRS) pada ibu menopause di Desa Sanggrahan RW 09, Banyuraden, Sleman Yogyakarta.

\section{METODE PENELITIAN}

Desain penelitian yang digunakan adalah survey deskriptif. yang dilakukan untuk menggambarkan tingkat keluhan berdasarkan Menopause Rating Scale (MRS) pada wanita menopause.

\section{HASIL DAN PEMBAHASAN}

Berdasarkan hasil uji statistik didapatkan hasil sebagaimana didalam tabel 1.
Tabel 1 Distribusi Frekuensi Karakteristik Responden

\begin{tabular}{clcc}
\hline No & Variabel & Frekuensi & $\begin{array}{c}\text { Persentase } \\
(\%)\end{array}$ \\
\hline 1. & Umur & & \\
& $50-54$ & 14 & 46.6 \\
& 55-59 & 16 & 53.3 \\
2. & Pendidikan & & \\
& SD & 16 & 53.3 \\
& SMP & 11 & 33.3 \\
& SMA & 3 & 9.1 \\
& PT & 0 & 0 \\
3. & Pekerjaan & & \\
& IRT & 12 & 36.4 \\
& Buruh & 8 & 24.2 \\
& Swasta & 10 & 33.3 \\
& PNS & 0 & 0 \\
\hline
\end{tabular}

Berdasarkan tabel 1 diketahui bahwa mayoritas responden berumur 55-59 tahun sebanyak 16 orang (53.3\%), mayoritas responden berpendidikan SD sebanyak 16 orang (53.3\%), dan mayoritas responden bekerja sebagai ibu rumah tangga (IRT) sebanyak 12 orang (36.4\%).

Tabel 2 Distribusi Frekuensi Responden Berdasarkan Keluhan Vasomotor Pada Wanita Menopause Di Desa Sanggrahan RW.09 Banyuraden Sleman, Yogyakarta

\begin{tabular}{|c|c|c|c|c|c|c|c|c|}
\hline \multirow{3}{*}{$\begin{array}{c}\text { Pernya } \\
\text { taan }\end{array}$} & \multicolumn{8}{|c|}{ Pilihan Jawaban } \\
\hline & $\begin{array}{c}\text { Tidak } \\
\text { Ada }\end{array}$ & Rin & gan & & Sedang & Berat & $\begin{array}{r}\mathrm{San} \\
\mathrm{Be}\end{array}$ & $\begin{array}{l}\text { ngat } \\
\text { erat }\end{array}$ \\
\hline & $\mathrm{F} \%$ & $\mathrm{~F}$ & $\%$ & $\mathrm{I}$ & $\%$ & $\mathrm{~F} \quad \%$ & $\mathrm{~F}$ & $\%$ \\
\hline $\begin{array}{l}\text { Badan } \\
\text { Terasa } \\
\text { Sangat } \\
\text { Panas, } \\
\text { Berker } \\
\text { ingat }\end{array}$ & 517 & 15 & 50 & 5 & 17 & 413 & 1 & 3 \\
\hline
\end{tabular}


Berdasarkan tabel 2 pada keluhan mayoritas responden memiliki gejala vasomotor menunjukkan bahwa ringan yaitu 15 responden ( $50 \%$ ).

Tabel 3 Distribusi Frekuensi Responden Berdasarkan Keluhan Psikologis Pada Wanita Menopause di Desa Sanggrahan RW.09 Banyuraden Sleman, Yogyakarta

\begin{tabular}{|c|c|c|c|c|c|c|c|c|c|c|}
\hline \multirow{3}{*}{ Pernyataan } & \multicolumn{10}{|c|}{ Pilihan Jawaban } \\
\hline & \multicolumn{2}{|c|}{ Tidak Ada } & \multicolumn{2}{|c|}{ Ringan } & \multicolumn{2}{|c|}{ Sedang } & \multicolumn{2}{|c|}{ Berat } & \multicolumn{2}{|c|}{$\begin{array}{l}\text { Sangat } \\
\text { Berat }\end{array}$} \\
\hline & $\mathrm{F}$ & $\%$ & $\mathrm{~F}$ & $\%$ & $\mathrm{~F}$ & $\%$ & $\mathrm{~F}$ & $\%$ & $\mathrm{~F}$ & $\%$ \\
\hline $\begin{array}{l}\text { Badan Terasa Sangat Panas, } \\
\text { Berkeringat }\end{array}$ & 5 & 16.7 & 15 & 50 & 5 & 16.7 & 4 & 1.3 .3 & 1 & 3.3 \\
\hline Masalah Tidur & 8 & 26.7 & 16 & 53 & 2 & 6.7 & 4 & 13.3 & 0 & 0 \\
\hline $\begin{array}{l}\text { Perasaan tertekan (merasa } \\
\text { tertekan, sedih, mudah menangis, } \\
\text { tidak bergairah/lesu, mood } \\
\text { berubah-ubah) }\end{array}$ & 6 & 20 & 12 & 40 & 9 & 30 & 3 & 10 & 0 & 0 \\
\hline $\begin{array}{l}\text { Mudah marah (merasa gugup, } \\
\text { rasa marah, agresif) }\end{array}$ & 6 & 20 & 15 & 50 & 6 & 20 & 3 & 10 & 0 & 6 \\
\hline $\begin{array}{l}\text { Rasa resah (rasa gelisah, rasa } \\
\text { panik) }\end{array}$ & 11 & 36.6 & 14 & 46.7 & 3 & 10 & 2 & 6.7 & 0 & 0 \\
\hline $\begin{array}{l}\text { Kelelahan fisik dan mental } \\
\text { (menurunnya kinerja secara } \\
\text { umum, berkurangnya daya ingat, } \\
\text { menurunnya konsentrasi, mudah } \\
\text { lupa/pikun) }\end{array}$ & 3 & 10 & 15 & 50 & 10 & 33.3 & 2 & 6.7 & 0 & 3 \\
\hline $\begin{array}{l}\text { Masalah-masalah } \\
\text { (perubahan dalam gairah seksual } \\
\text { aktifitas seksual dan kepuasan } \\
\text { seksual) }\end{array}$ & 4 & 13.3 & 18 & 60 & 5 & 16.7 & 3 & 10 & 0 & 4 \\
\hline $\begin{array}{l}\text { Masalah-masalah pada kandung } \\
\text { dan saluran kemih (sulit buang air } \\
\text { kecil, sering buang air kecil, } \\
\text { buang air kecil yang tidak } \\
\text { terkontrol) }\end{array}$ & 15 & 50 & 12 & 40 & 2 & 6.7 & 1 & 3.3 & 0 & 15 \\
\hline $\begin{array}{l}\text { Kekeringan pada vagina (rasa } \\
\text { kering atau terbakar pada vagina, } \\
\text { kesulitan dalam berhubungan } \\
\text { intim) }\end{array}$ & 2 & 6.7 & 24 & 80 & 2 & 6.7 & 2 & 6.7 & 0 & 2 \\
\hline
\end{tabular}


Berdasarkan Tabel 3 hasil pilihan jawaban keluhan psikologis wanita menopause didapati bahwa paling banyak responden memiliki tidak ada gejala pada pernyataan masalahmasalah pada rasa tidak nyaman pada jantung (detak jantung yang tidak biasa, jantung berdebar) yaitu sebanyak 18 responden $(60 \%)$, yang memilih gejala ringan pada pernyataan kekeringan pada vagina (rasa kering atau terbakar pada vagina, kesulitan dalam berhubungan intim) yaitu sebanyak 24 responden (80\%), yang memilih gejala sedang pada pernyataan Kelelahan fisik dan mental (menurunnya kinerja secara umum, berkurangnya daya ingat, menurunnya konsentrasi, mudah lupa/pikun) sebanyak 10 responden (33.3\%), yang memilih gejala berat pada pernyataan Masalah Tidur (susah tidur, susah untuk tidur nyenyak, bangun terlalu pagi) sebanyak 4 responden $(13.3 \%)$.

Keluhan yang paling sedikit responden memilih tidak ada gejala pada pernyataan Kekeringan pada vagina (rasa kering atau terbakar pada vagina, kesulitan dalam berhubungan intim) sebanyak 2 responden (6.7\%), gejala ringan pada pernyataan rasa tidak nyaman pada jantung (detak jantung yang tidak biasa, jantung berdebar) sebanyak 8 responden $(26.7 \%)$. Gejala sedang pada pernyataan Masalah Tidur (susah tidur, susah untuk tidur nyenyak, bangun terlalu pagi), Masalah-masalah pada kandung dan saluran kemih (sulit buang air kecil, sering buang air kecil, buang air kecil yang tidak terkontrol), Kelelahan fisik dan mental (menurunnya kinerja secara umum, berkurangnya daya ingat, menurunnya konsentrasi, mudah lupa/pikun) yaitu sebanyak 2 responden (6.7\%), sedangkan keluhan yang paling sedikit pada gejala berat adalah Masalahmasalah pada kandung dan saluran kemih (sulit buang air kecil, sering buang air kecil, buang air kecil yang tidak terkontrol) sebanyak 1 responden $(3.3 \%)$.

Tabel 4 Distribusi Frekuensi Responden Berdasarkan Keluhan Somatik Pada Wanita Menopause Di Desa Sanggrahan RW.09 Banyuraden Sleman, Yogyakarta.

Pilihan Jawaban

\begin{tabular}{lcccccccccc}
\multirow{2}{*}{ Pernyatan } & \multicolumn{3}{c}{ Tidak Ada } & \multicolumn{2}{c}{ Ringan } & \multicolumn{2}{c}{ Sedang } & \multicolumn{2}{c}{ Berat } & \multicolumn{2}{c}{ Sangat Berat } \\
\cline { 2 - 11 } & F & $\%$ & F & $\%$ & F & $\%$ & F & $\%$ & F & $\%$ \\
\hline $\begin{array}{l}\text { Rasa tidak nyaman pada persendian dan otot } \\
\text { (sakit pada persendian, keluhan rematik }\end{array}$ & 5 & 16.7 & 15 & 50 & 5 & 16.7 & 4 & 13 & 1 & 3.3 \\
\hline
\end{tabular}


Berdasarkan Tabel 4 hasil pilihan jawaban keluhan somatic pada pernyataan rasa tidak nyaman pada sendi dan otot (sakit pada persendian, keluhan rematik) menunjukkan bahwa mayoritas responden memilih gejala sedang yaitu sebanyak 10 responden (33.3 \%) dan minoritas responden memilih gejala sangat berat yaitu 2 responden $(6.7 \%)$.

Skala penilaian menopause adalah skala kualitas hidup yang dikembangkan di tahun 90an untuk menilai tingkat keluhan menopause sebagai respon terhadap kurangnya skala ukur yang terstandarisasi untuk menilai keparahan gejala menopause serta efeknya terhadap kualitas hidup (Schorage, 2008). Menopouse mengakibatkan pengurangan produksi hormon estrogen hingga jumlahnya menjadi $<20$ pikogram $/ \mathrm{ml}$. Hal ini berdampak pada munculnya beberapa keluhan pada wanita menopause sehingga menimbulkan kecemasan. Keluhan tersebut diantaranya diantaranya keluhan vasomotor, keluhan psikologis dan keluhan somatik (Ferrari, 2009).

\section{Keluhan Vasomotor}

Keluhan vasomotor merupakan gejolak rasa panas (hot flushes) dan berkeringat dimalam hari. gejolak rasa panas (hot flushes) merupakan gejala vasomotor yang menjadi keluhan paling sering dirasakan pada wanita menopause, prevalensinya di dunia adalah 70-80\% (Siregar, 2014). Hal ini sesuai dengan hasil penelitian yang dilakukan dengan alat ukur Menopause Rating Scale (MRS) pada tabel 4.2 bahwa dari 30 wanita menopause yang diteliti menggunakan Menopause Rating Scale (MRS), ditemukan mayoritas responden memilih gejala ringan yaitu 15 responden (50\%) dan minoritas memilih gejala berat yaitu 1 responden $(3.3 \%)$.

Hot flushes terkait dengan vasodilatasi dan peningkatan suhu kulit yang menghasilkan keringat, penurunan resistensi kulit, dan peningkatan konduktansi kulit. Investigasi kemudian menunjukkan bahwa penarikan estrogen adalah faktor pencetus untuk terjadinya hot flushes pada wanita menopause. Rasa panas ini tidak membahayakan dan akan cepat hilang. Akan tetapi hal ini membuat rasa tidak nyaman. Pemberian estrogen dalam bentuk terapi efektif meredakan gejolak rasa panas (hot Flushes). Rasa panas yang di derita ini biasanya berhubungan erat dengan cuaca panas dan lembab. Selain itu juga 
berhubungan dengan ruang sempit, kafein, alcohol atau makanan pedas, sehingga perlu dihindari penggunaan baju yang terlalu ketat, tidak menyerap keringat, hindari makanan pedas, kaffein dan alcohol (Siregar, 2014).

2. Keluhan Psikologis

Keluhan psikologis yang terjadi berupa hilang minat pada berbagai macam hal khususnya berhubungan seksual, sulit tidur, perasaan tegang atau tertekan, mudah tersinggung, mudah panic, sulit berkonsentrasi, mudah lelah, perasaan tidak bahagia dan mudah menangis. Hal ini sesuai dengan pendapat Varney (2006) yang menyatakan bahwa trias gejala psikologi yang sering kali disebut ada hubungannya dengan masa menopause adalah depresi dalam perasaan, insomnia dan penurunan minat seksual. Gejala psikologis ini merupakan dasar terhadap sifat sindrom depresi pada wanita menopause. Hal ini dikarenakan pada masa menopause kadar hormone estrogen menurun drastis sehingga memengaruhi fungsi tubuh (Ferrari, 2009).

Berdasarkan tabel 4.3 dapat dilihat bahwa dari 30 responden yang diteliti, ditemukan mayoritas responden memilih gejalan ringan pada pernyataan kekeringan pada vagina (rasa kering atau terbakar pada vagina, kesulitan dalam berhubungan intim) yaitu sebanyak 24 responden (80\%). Kekeringan pada vagina dikarenakan adanya penurunan kadar hormone estrogen yang menyebabkan pada vagina akan terlihat adanya perubahan yang terjadi pada lapisan dinding vagina. Pada masa menopause vagina akan terlihat menjadi lebih kering dan kurang elastis. Efek dari gejala ini maka akan timbul rasa sakit pada saat melakukan hubungan seksual, sehingga membuat ibu menopause menjadi depresi (Rosella, 2008). Untuk mengatasinya, ibu menopause bisa menggunakan pelumas vagina atau krim sebagai pengganti hormone estrogen dengan mengusapkannya pada vagina dan melakukan komunikasi dengan suami agar melakukan foreplay lebih lama. Hal ini bisa menyebabkan rasa tenang dan nyaman pada ibu menopause dalam melakukan hubungan seksual (Rosella, 2008).

Pada tabel 4.3 juga terdapat keluhan psikologis ringan pada masalah tidur (susah tidur, susah untuk tidur nyenyak, bangun terlalu pagi) sebanyak 16 responden (16.3\%). Kestabilan emosi selama masa 
perimenopause dapat terganggu oleh pola tidur yang buruk. Hot flushes tidak memiliki dampak yang merugikan pada kualitas tidur. Pada hasil penelitian juga ditemukan gejala ringan berupa mudah marah (merasa gugup, rasa marah, agresif) sebanyak 15 responden (50\%).

Dalam sebuah penelitian disebutkan bahwa perempuan memiliki risiko lebih tinggi untuk mengalami gangguan suasana hati/mood bila dibandingkan dengan pria, hal ini terkait dengan periode menopause yang dialami wanita. Lebih dari $70 \%$ wanita pada masa perimenopause mudah menangis dan tidak merasa bahagia, lebih dari $60 \%$ merasakan kecemasan, depresi dan penurunan daya ingat (Chedrau, 2011).

Dalam penelitian, prevalensi perubahan mood meningkat dari premenopause ke perimenopause awal, dari sekitar $10 \%$ menjadi sekitar 16,5 $\%$, Ada tiga kemungkinan: penurunan estrogen saat menopause mempengaruhi neurotransmitter yang mengatur mood, (2) mood dipengaruhi oleh gejala vasomotor (3) mood dipengaruhi oleh perubahan hidup yang umumnya lazim disekitar masa menopause. Beberapa dapat berpendapat bahwa perubahan mood ini dalam menanggapi fluktuasi hormonal terjadi selama tahun-tahun perimenopause (Siregar, 2014).

3. Keluhan Somatik

Berdasarkan tabel 4.4 dapat dilihat bahwa dari 30 responden yang diteliti dengan menggunakan Menopause Rating Scale (MRS), ditemukan mayoritas responden memilih gejala sedang pda pernyataan Rasa tidak nyaman pada persendian dan otot (sakit pada persendian, keluhan rematik) yaitu ssebanyak 10 responden (33.3 \%) dan minoritas responden memilih tidak ada gejala sebanyak 4 responden $(13.3 \%)$.

Beberapa gejala somatik yang sering terjadi selama perimenopause antara lain, sakit kepala, pusing, palpitasi serta payudara yang membesar dan nyeri. Dari semua keluhan-keluhan di atas, harus diyakinkan bahwa gejalagejala tersebut umum terjadi dan bersifat fisiologis. Pengobatan yang dilakukan bersamaan dengan pendidikan dan suportif harus dilakukan pada awal timbulnya gejala. Sekarang ini terapi farmakologi dan nonfarmakologi sudah tersedia. Tidak ada alasan untuk mengatakan bahwa tidak ada pengobatan bagi wanita pada masa perimenopause, sebab mereka 
masih menghasilkan estrogen. Dalam banyak kasus, meyakinkan bahwa gejala-gejala tersebut adalah hal yang nyata dan tidak mengancam kehidupan mungkin sudah cukup. Tetapi, jika dianggap penting, pengobatan tidak harus ditunda (Sinclair, 2009).

\section{SIMPULAN DAN SARAN}

Tingkat Keluhan menopause berdasarkan Menopause Rating Scale (MRS) menunjukkan mayoritas wanita menopause mengalami gejala ringan pada keluhan psikologis berupa kekeringan pada vagina (rasa kering atau terbakar pada vagina, kesulitan dalam berhubungan intim) sebanyak 24 responden $(80 \%)$.

Hasil penelitian ini diharapkan dapat menjadi masukan bagi setiap petugas kesehatan dalam meningkatkan pemberian informasi dan pemahaman tentang keluhan yang dialami wanita selama menopause.

\section{DAFTAR PUSTAKA}

Dinas Kesehatan DIY. 2013. Profil Kesehatan Daerah Istimewa Yogyakarta tahun 2013. Yogyakarta: Dinas Kesehatan DIY

Ferrari A. Soy extract phytoestrogen with high dose of isoflavons for menopausal syntoms. J Obstet Gynecol Res.2009;35(6):108390.

Klein NA, Soules MR. Endocrine changes of the menopause. Clin Obstet Gynecol 2004;41:912-20

Mulyani, S, 2013. Menopause Akhir Siklus Menstruasi Pada Wanita di Usia Pertengahan. Yogyakarta: Nuha Medika.

Rossella, E \& Esme, A 2008. Women's perception of sexual around the menopause: Outcomes of European telephone survey. European Journal of Obstetric \& Gynecology and Reproductive Biology.

Sinclair C. Buku Saku Kebidanan. Jakarta:EGC;2009. 
Siregar MFG. Perimenopausal and Postmenopausal Complaints in Paramedics Asseds by Menopause Rating Scale in Indonesia. IQSR-JDMS, Volume 13, Issue 12 Ver.I, PP 38-42, 2014.

Schorge et al. 2008. Menopause dalam Williams Gynecology edisi 23. New York: The McGraw-Hill Companies.
Wang ZL, Zhuo SY, Lu W. Liao HF, Verbruggen M, Fang S, dkk. Soy germ isoflavons improve menopausal symtoms but have no effect on blood lipids in early postmeopausal Chinese women: a randomized placebo-contolled trial. Menopause J.2012;19(7):7918 